\title{
Biological Potential of Products Obtained from Palm Trees of the Genus Syagrus
}

\author{
Davi de Lacerda Coriolano $\left(\mathbb{D},{ }^{1}\right.$ Maria Helena Menezes Estevam Alves $(\mathbb{D})^{1}$ \\ and Isabella Macário Ferro Cavalcanti (iD) \\ ${ }^{1}$ Federal University of Pernambuco (UFPE), Laboratory of Immunopathology Keizo Asami (LIKA), Recife, Pernambuco, Brazil \\ ${ }^{2}$ Federal University of Pernambuco (UFPE), Laboratory of Microbiology and Immunology, Academic Center of Vitória (CAV), \\ Vitória de Santo Antão, Pernambuco, Brazil
}

Correspondence should be addressed to Isabella Macário Ferro Cavalcanti; isabella.cavalcanti@ufpe.br

Received 3 February 2021; Accepted 10 August 2021; Published 20 August 2021

Academic Editor: Samuel Martins Silvestre

Copyright (C) 2021 Davi de Lacerda Coriolano et al. This is an open access article distributed under the Creative Commons Attribution License, which permits unrestricted use, distribution, and reproduction in any medium, provided the original work is properly cited.

\begin{abstract}
Medicinal plants have been used for centuries by communities worldwide, as they have diverse biological properties and are effective against numerous diseases. The genus Syagrus stands out for its versatility and for so many activities presented by these palm trees, mainly due to its rich chemical and fatty acid compositions. The genus has antibacterial potential, has antibiofilm, antiparasitic, antioxidant, prebiotic, antiulcerogenic, anticholinesterase, and hypoglycemic activities, and can produce biodiesel, amid others. Among all species, Syagrus coronata and Syagrus romanzoffiana stand out, presenting the greatest number of activities and applications. The secondary metabolites obtained from these palm trees present high activity even in low concentrations and can be used against infections and chronic diseases. Furthermore, these plants have been used in some communities for years and have presented healing properties, especially in inflammatory processes. Therefore, the Syagrus genus proves to be promising, which shows a lot of therapeutic potential.
\end{abstract}

\section{Introduction for Genus Syagrus}

Currently, medicinal plants and bioactive compounds have a major research focus because there are several reports on their biological properties, therefore leading to high demand for these plants [1]. They have been used for centuries by different communities around the world, and they have different biological properties and are effective against numerous diseases [2]. Commonly used in Chinese herbal medicine for disease prevention, treatment, and cure for thousands of years [3], as well as in Ancient Mesopotamia and Egypt, as reported in the Bible [4], these plants and their compounds had a substantial role in the treatment of several acute and chronic diseases throughout centuries [5].

According to the World Health Organization (WHO), the use of traditional medicine practices grows around the world, including herbal medicine as the only form of therapy [6]. The use of these plants appears mainly in the forms of extracts and oils; however, studies are applied to isolate molecules, understand and formulate herbal medicines to combat infectious and chronic diseases [7]. Besides the traditional communities, the pharmaceutical industry is widely using natural compounds in their formulations, as well as using biotechnology to produce bioactive molecules isolated from plants on a large scale, especially due to the fact that plants are safer, have a lower cost, and better availability [8].

The pharmacological potential of these plants is due to secondary plant metabolism, a set of metabolic processes responsible for the interactions with the environment and the production of secondary metabolites with diverse biological and physio-chemical properties, like phenolic compounds, organic acids, terpenes, alkaloids, among others [9]. These secondary metabolites are produced under specific abiotic stress and pathogenic attacks, thus the production of these chemicals is a form of protection to the plant $[10,11]$. In addition to those plants and their secondary metabolites pharmacological properties, some plants used in traditional 
medicine are also exploited in their areas, such as biotechnology, for the production of biodiesel, enzymes, bioremediation, and others, therefore expanding the dimension to humanity's usage of plants [12-14].

Many genera of plants from the Arecaceae family all around the world have been used in traditional medicine and have shown biological activity. The genus Butia from the Arecaceae family and the subfamily Arecoideae is prevalent in southern Brazil, eastern Paraguay, northeastern Argentina, and in the northwest and southeast of Uruguay, and presents many properties, such as antibacterial, anti-inflammatory, and antioxidant activities [15]. The genus Euterpe from the Arecaceae family and the subfamily Arecoideae, found abundantly in Brazil, also shows various biological activities, such as anti-inflammatory, antioxidant, antimicrobial, antinociceptive, anticancer, and antiatherogenic, among others [16, 17]. The genus Elaeis also from the Arecaceae family is native to Africa and areas of South and Central America and also presents numerous activities, among them antiparasitic and wound-healing properties [18].

With greater prevalence of the Arecaceae family in South America and mainly in the north and northeast of Brazil, the Syagrus genus stands out for its versatility. This genus of palm trees has 65 species, 2 subspecies, 14 natural hybrids, and several applications [19]. Belonging to the family Arecaceae and the subfamily Arecoideae, the species of the genus Syagrus has great socioeconomic importance in tropical savanna flora. These palm trees can grow in several areas, such as tropical, humid subtropical, semiarid, and cerrado areas, showing a variety of habitat with different climates [19-21], this reflects the fact that these plants are used by many communities as a nutritional source [22], in addition to being considered a therapeutic option due to its antibacterial [23], antiparasitic [24], antioxidant [25], hypoglycemic [26] activities, and other promising actions of this genus.

Thus, this work is important and innovative because it is the first review that highlights the biological potential and pharmacological properties of palm trees from the genus Syagrus and their promising approaches to the development of new therapeutic alternatives.

1.1. Methodology and Strategies. The elaboration of this review was based on the following stages: identification of the theme and development of the guiding question; establishment of inclusion and exclusion criteria, analysis, and selection of articles; interpretation of data and results; and the writing of this paper. The guiding question was "What are the biological properties of genus Syagrus palm trees?" The inclusion criteria adopted were studies related to the proposed theme published in either Portuguese or English between 2005 and 2021, indexed on online databases, such as U.S. National Library of Medicine (PubMed), ScienceDirect, Scopus, and Scientific Electronic Library Online (SciELO). Both reviews and original articles were included. In turn, repeated studies, studies that do not address the proposed theme, incomplete studies, duplicates, and monographs were excluded.
After the literary search, 80 articles were selected using the inclusion and exclusion criteria. The analysis of the selected studies made it possible to identify variables, observations, and data that gathered the knowledge about the potential of Syagrus palm trees. Both the analysis and the relationship of the data extracted from these articles were developed descriptively, making it possible to count, observe, describe, classify, and organize the knowledge generated about Syagrus palm trees' properties.

\section{Biological Properties of Plants of the Syagrus Genus}

2.1. Antibacterial Activity. Bacterial infections are a major public health problem worldwide, especially due to the high levels of resistance to antimicrobials, consequently resulting in failure treatments, hospital readmissions or prolonged hospitalizations, high rates of morbidity and mortality, and high costs to health systems. With the phenomenon of bacterial resistance associated with little discovery of drugs, the search for new therapeutic options of low cost and greater efficacy has found space and strength in the study of natural products against sensitive and resistant bacterial strains, especially against Staphylococcus aureus [27-29].

Silveira et al. [30] studied the antibacterial activity of the fruit and almond extracts of Syagrus oleracea, popularly known as guariroba, and tested against Staphylococcus aureus ATCC 25923, Pseudomonas aeruginosa ATCC 27853, and Escherichia coli ATCC 25922, inhibiting bacterial growth up to $74 \%$ (Table 1). Hughes [23] analyzed the antimicrobial potential of Syagrus coronata, popularly known as ouricuri or licuri, evaluating its potential against Bacillus cereus CCMB 282, S. aureus CCMB 285, S. aureus CCMB 262 (resistant to streptomycin and dihydrostreptomycin), and S. aureus CCMB 263 (resistant to novobiocin) (Table 1). The extracts showed antibacterial activity with minimum inhibitory concentrations ranging from 190 to $3120 \mu \mathrm{g} / \mathrm{mL}$. This activity was probably related to the complex that phenolic compounds in the extracts formed with extracellular proteins of the bacterial membrane.

Bessa et al. [27] evaluated the activity of essential oil and commercial oil of $S$. coronata against the strain of $S$. aureus UFPEDA 02 and clinical isolates of methicillin-resistant $S$. aureus (MRSA) and methicillin-sensitive $S$. aureus (MSSA) (Table 1). Bacteriostatic and bactericidal effects were observed when both oils were tested in all of the samples, although a higher concentration of the commercial oil was required.

In the study conducted by Santos et al. [31], antiS. aureus activity was also evaluated from the essential oil of $S$. coronata seeds, and similar results were observed for both S. aureus UFPEDA 02 strain, and multidrug-resistant S. aureus clinical isolates (Table 1). In this same study, an in vivo experiment with Galleria mellonema was performed, and it was observed that the treatment with essential oil of $S$. coronata in infected larvae increased the survival rate of the larvae by $60 \%$. In addition, a reduction of $4 \log \mathrm{CFU} / \mathrm{mL}$ in bacterial load was observed after 3 days of treatment. 
TABle 1: Antibacterial activity of compounds extracted from Syagrus genus.

\begin{tabular}{|c|c|c|c|c|}
\hline Plant & Popular name & Natural compounds & Bacteria & References \\
\hline $\begin{array}{l}\text { Syagrus } \\
\text { oleracea }\end{array}$ & Guariroba & Hexane fraction of the epicarp/mesocarp & $\begin{array}{c}\text { Staphylococcus aureus ATCC } 25923 \\
\text { Pseudomonas aeruginosa ATCC } 27853 \\
\text { Escherichia coli ATCC } 25922\end{array}$ & [27] \\
\hline $\begin{array}{l}\text { Syagrus } \\
\text { coronate }\end{array}$ & $\begin{array}{l}\text { Ouricuri or } \\
\text { licuri }\end{array}$ & Aqueous inflorescence extract & $\begin{array}{l}\text { Bacillus cereus CCMB } 282 \\
\text { S. aureus CCMB } 262 \\
\text { S. aureus CCMB } 263 \\
\text { S. aureus CCMB } 285\end{array}$ & {$[20]$} \\
\hline $\begin{array}{l}\text { Syagrus } \\
\text { coronate }\end{array}$ & $\begin{array}{l}\text { Ouricuri or } \\
\text { licuri }\end{array}$ & $\begin{array}{l}\text { Essential oil and commercial oil extracted } \\
\text { from the seeds }\end{array}$ & $\begin{array}{l}\text { S. aureus UFPEDA } 02 \\
\text { Methicillin-resistant } S \text {. aureus (MRSA) } \\
\text { clinical isolate } \\
\text { Methicillin-sensitive } S \text {. aureus (MSSA) } \\
\text { clinical isolate }\end{array}$ & {$[24]$} \\
\hline $\begin{array}{l}\text { Syagrus } \\
\text { coronata }\end{array}$ & $\begin{array}{c}\text { Ouricuri or } \\
\text { licuri }\end{array}$ & Essential oil extracted from the seeds & $\begin{array}{c}\text { S. aureus UFPEDA } 02 \\
\text { Multidrug-resistant S. aureus }\end{array}$ & {$[28]$} \\
\hline
\end{tabular}

Therefore, evidencing the antibacterial potential of natural products extracted from plants of this genus, highlighting the anti-S. aureus activity from the essential oil of $S$. coronata, which is rich in compounds with this property, such as lauric, oleic, and linoleic acids [27].

The mechanism of action of both $S$. coronata and S. oleracea is not fully elucidated, but lauric acid, one of the main compounds in those plants, acts on the destruction of the cell membrane and interferes with cellular processes, such as signal transduction and transcription [32, 33]. Capric acid, also one of the main compounds in those plants, can damage the bacterial membrane due to its hydrophobicity, thereby facilitating the entrance of hydrogen ions from the extracellular environment and the complete inactivation of the bacterial cells $[33,34]$.

Besides that, $S$. coronata oil was proved to be safe when evaluated by biochemical, hematological, and histological parameters and did not demonstrate mutagenic nor genotoxic effects even in high doses [35].

2.2. Antibiofilm Activity. Biofilms are complexes composed of a set of bacteria encapsulated in an array of extracellular polymeric substances linked to biotic or abiotic surfaces. This system offers greater security, stability, oxygen, and nutrients to the microorganisms of this complex, thus protecting them from stress and increasing their survival potential [36]. This virulence factor is the main agent responsible for chronic infections because this persistence conferred by the biofilm results in treatment failure, making it necessary to apply new therapeutic approaches [37].

In the study of Santos [31], with the essential oil of $S$. coronata rich in dodecanoic acid, it was evaluated the activity of this oil against the biofilm of $S$. aureus UFPEDA 02. As a result, a significant reduction in the matrix was observed of biofilm only at concentrations of 312 and $624 \mu \mathrm{g} / \mathrm{mL}$; however, the viability of biofilm cells was significantly reduced at all concentrations tested, showing a reduction greater than $50 \%$ in the concentration of $156 \mu \mathrm{g} / \mathrm{mL}$ and a reduction of almost $100 \%$ at concentrations of 624 and $1248 \mu \mathrm{g} / \mathrm{mL}$. In addition, changes in the cellular structure of $S$. aureus were also observed, as well as a loss of roughness in the multiple layers of the threedimensional structure of the bacterial biofilm.

Another similar research performed by Junior [38] evaluated the antibiofilm activity of the essential oil of $S$. coronata, rich in dodecanoic, decanoic, and octanoic acids, against the Proteus mirabilis UFPEDA 737 isolate. Above $500 \mu \mathrm{g} / \mathrm{mL}$, the essential oil inhibited biofilm formation by more than $55 \%$. The mechanism of action of $S$. coronata is not fully elucidated, but its main compounds lauric acid, capric acid, and caprylic acid affect cell membranes and bacterial adhesins, virulence genes, capsule production, and cell adhesion, respectively [39].

2.3. Antiparasitic Activity. Even in modern society, parasitic infections are still one of the world's public health problems, causing millions of deaths each year. Parasitic infections are considered as neglected tropical diseases, mainly because they mostly affect people in underdeveloped countries, where a large part of the population lives in a situation of social vulnerability. Many of these diseases have high cytotoxicity treatment so new therapeutic alternatives are needed to fight these infections $[40,41]$.

Leishmaniasis is an endemic parasitic infection caused by more than 20 species of Leishmania. Present in 97 countries, leishmaniasis affects more than 1.3 million people every year. This infection has three main forms: cutaneous leishmaniasis, visceral leishmaniasis, and mucocutaneous leishmaniasis [42]. The treatment of leishmaniasis is very problematic, due to the increase in parasitic resistance to currently used therapies, serious side effects, unsatisfactory results, and high cost of treatment [43].

Rodrigues et al. [24] analyzed the anti-Leishmania amazonensis activity of the aqueous polymeric extract of $S$. coronata rich in procyanidin. They tested the potential of this extract against the promastigote and amastigote forms of L. amazonensis. The extract of S. coronata, at a concentration of $50 \mu \mathrm{g} / \mathrm{mL}$, was able to inhibit the growth of promastigotes after 30 minutes and make $100 \%$ of the promastigotes unviable after 60 minutes. In addition, increased cell volume and membrane rupture were observed in 
the promastigotes treated with aqueous extract, suggesting that the extract of $S$. coronata induced osmotic dysregulation in L. amazonensis promastigotes (Figure 1). In the same study, the extract of $S$. coronata was also able to reduce the index of association between macrophages and amastigotes of L. amazonensis, with a concomitant increase in the production of nitric oxide (NO). When mouse peritoneal macrophages were pretreated with the extract at a concentration of $33 \mu \mathrm{g} / \mathrm{mL}$, the association index was reduced by $70.4 \%$, and NO production increased by $158.3 \%$ when compared to the control. When the treatment was applied 24 hours after macrophage infection, the $33 \mu \mathrm{g} / \mathrm{mL}$ of the crude aqueous extract was able to reduce the association index by $71 \%$ and increase NO production by $90.4 \%$. Therefore, demonstrating the potential of using this plant as a leishmanicidal drug, mainly due to the increase in NO production, which potentiates the mechanisms of death of L. amazonensis.

Chagas disease or American trypanosomiasis is an anthropozoonosis caused by Trypanosoma cruzi. This infection is also considered a neglected tropical disease and is an important social and public health problem in Latin America. The number of people infected with T. cruzi in the world is substantial, being between 6 and 7 million people infected. The treatment of Chagas disease is effective in patients in the acute phase of the disease; however, when the person has been infected for a long period, the effectiveness of the medication decreases, and the treatment becomes ineffective. In addition, the drug can cause side and adverse effects due to its high cytotoxicity to mammalian cells $[44,45]$.

Souza et al. [46] evaluated the trypanocidal activity of the essential oil of $S$. coronata seeds. Their results showed that half of the maximal inhibitory concentration $\left(\mathrm{IC}_{50}\right)$ for T. cruzi epimastigotes was $100.6 \pm 38 \mu \mathrm{g} / \mathrm{mL}$, the $\mathrm{IC}_{50}$ for amastigotes was $408.33 \pm 23.36 \mu \mathrm{g} / \mathrm{mL}$ and the lethal concentration $\left(\mathrm{LC}_{50}\right)$ for trypomastigotes was $182.49 \pm 58.05 \mu \mathrm{g} /$ $\mathrm{mL}$. Thus, it was demonstrated that the essential oil of $S$. coronata was able to inhibit the growth of epimastigotes and decrease the viability of trypomastigotes with moderately toxic concentrations.

2.4. Antioxidant Activity. In metabolisms, there are several oxidative processes necessary for cell survival. These processes result in the production of free radicals, which are involved in a series of regulatory processes, such as cell proliferation, apoptosis, and gene expression. However, in excess, these free radicals cause changes in protein structure, amino acid oxidation, DNA damaging, aging, and other harms. Therefore, in recent years there has been an increase in the demand for molecules and products that protect the individual against oxidative stress, and plants have been shown to be strong candidates due to their chemical compositions [47, 48].

Andrade et al. [49] studied the antioxidant activity of Syagrus romanzoffiana, popularly known as Jerivá. This property of the plant was evaluated using the $\beta$-carotene/ linoleic acid method, which assesses the activity of inhibiting free radicals formed in lipid peroxidation, and ABTS and DPPH methods, which are related to the search for free radicals. Using $0.4 \mathrm{~mL}$ of extracts from the pulp and kernel cake of $S$. romanzoffiana, inhibition rates of oxidation were $97.00 \pm 0.43 \%$ and $95.13 \pm 0.7 \%$, respectively, when the $\beta$-carotene method was applied. The ABTS method also demonstrated high antioxidant activity in the samples, all of which were greater than $100 \mu \mathrm{M}$ Trolox $\cdot \mathrm{g}^{-1}$. Using $30 \mu \mathrm{L}$ of the pulp extract, a result of $2498.49 \pm 186.7 \mu \mathrm{M}$ Trolox. $\mathrm{g}^{-1}$ was obtained. In the same concentration of the kernel cake extract, the result was lower, obtaining $1314.87 \pm 29.78 \mu \mathrm{M}$ Trolox $\cdot g^{-1}$. In the DPPH method, the concentration necessary to reduce the amount of DPPH (EC50) was measured. The best result once again was from the pulp extract of S. romanzoffiana, presenting an $\mathrm{EC}_{50}=96.97 \pm 3.74 \mathrm{~g}$ fruit. ${ }^{-1}$ DPPH, whereas the kernel cake extract showed EC 50 of $331.80 \pm 3.95 \mathrm{~g}$ fruit. $\mathrm{g}^{-1} \mathrm{DPPH}$. The authors state that the large number of phenolic compounds in this oil may have contributed to this antioxidant activity [49].

According to Coimbra and Jorge [50], the antioxidant activity of Jerivá pulp oil can be justified by a large amount of $\beta$-carotene and tocopherols, with a total of $1219.01 \pm 16.21 \mu \mathrm{g} / \mathrm{g}$ for carotenoids and a total of $323.50 \pm 7.85 \mathrm{mg} / \mathrm{kg}$ for tocopherols, with $\alpha$-tocopherol being the most abundant $(273.53 \pm 4.79 \mathrm{mg} / \mathrm{kg})$. Both compounds have proven antioxidant activity in vivo and in vitro. $\beta$-Carotene can function as a lipid scavenger and an oxygen extinguisher because of its unique structure of conjugated double bonds and ionone rings [51], and tocopherols can deactivate reactive oxygen species, inhibit protein oxidation, and prevent the propagation of lipid peroxidation by scavenging lipid peroxyl radicals [52], thus showing their potent antioxidant activity.

Belviso et al. [25] evaluated the antioxidant activity of $S$. coronata using the methods of DPPH and ABTS. The extract of toasted $S$. coronata seeds showed better antioxidant activity, presenting $\mathrm{DPPH}=7.01 \pm 0.23 \mu \mathrm{MTE} / \mathrm{g}$ and $\mathrm{ABTS}=5.31 \pm$ $0.74 \mu \mathrm{MTE} / \mathrm{g}$, whereas the extract of raw seeds showed $\mathrm{DPPH}=5.88 \pm 0.16 \mu \mathrm{M}$ TE/ge $\mathrm{ABTS}=4.07 \pm 0.17 \mu \mathrm{M} \mathrm{TE} / \mathrm{g}$.

The antioxidant activity of $S$. oleracea was also tested in the studies by Silva et al. [53] and Siqueira et al. [54]; however, the results were not as promising as those found in the two plants shown above. In the study by Silva [53], the $\mathrm{EC}_{50}$ of S. oleracea extract in the DPPH test was $425.5 \pm 1.9 \mu \mathrm{g} / \mathrm{mL}$, this result demonstrates low antioxidant activity. Siqueira et al.'s [54] obtained rate inhibition of oxidation by the ß-carotene method was $0.7 \pm 0.1 \% / g$, a very low rate.

2.5. Prebiotic Activity. Approximately 100 trillion microorganisms are inhabiting the human gastrointestinal tract. This microbiota present in the gastrointestinal system is part of a complex ecosystem that plays an important role in maintaining people's well-being and health [55]. Prebiotics are compounds selectively used by host microorganisms that 


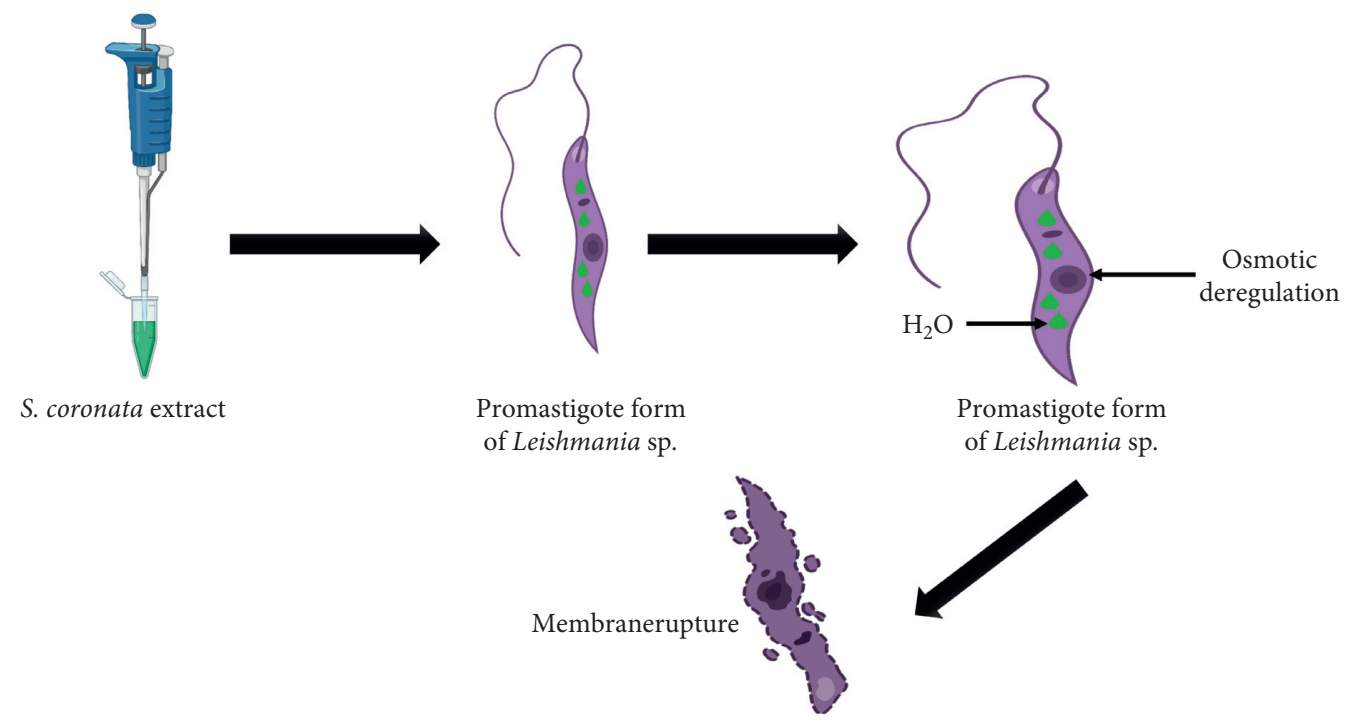

FIGURE 1: Mechanism of action of S. coronata extract against promastigote of Leishmania amazonensis (created with BioRender.com). Color indicates that Syagrus coronata aqueous extract increased cell volume and caused membrane rupture in the promastigotes due to osmotic dysregulation.

can promote health benefits to the individual. They can be used as an energy source and stimulate the growth of microorganisms in the intestinal microbiota. Despite the benefits, the prebiotics available are not easily accessible, due to the high cost, so new alternatives are sought, such as the use of medicinal plants $[49,56]$.

Andrade et al. [49] studied the prebiotic potential of $S$. romanzoffiana pulp and kernel cake through the analysis of factors such as microbial growth, fermentation, and organic acids produced by the strains Bifidobacterium lactis BLC1, Lactobacillus casei BGP93, and Lactobacillus acidophilus LA3, in addition to of the $\mathrm{pH}$ change. The $S$. romanzoffiana pulp showed the best results, showing significant growth of $9.09 \pm 0.09 \log \mathrm{CFU} / \mathrm{mL}, 9.20 \pm 0.11 \mathrm{log}$ $\mathrm{CFU} / \mathrm{mL}$, and $8.76 \pm 0.12 \log \mathrm{CFU} / \mathrm{mL}$ for B. lactis, L. casei, and $L$. acidophilus, respectively. The greater growth of the probiotic strains was the result of the use of the carbon present in the $S$. romanzoffiana pulp as an energy source for bacteria. A greater decrease in $\mathrm{pH}$ was also observed after the administration of the $S$. romanzoffiana pulp, proving once again the probiotic potential of the plant, since a reduction in $\mathrm{pH}$ can be caused by the production of organic acids such as lactic, acetic acid, propionic, and butyric by bacteria during fermentation, thus indicating bacterial growth of probiotic strains and possible inhibition of the proliferation of pathogenic bacteria.

2.6. Antiulcerogenic Activity. Peptic ulcers are an increasingly common problem in the world population, affecting millions of people every year. They are lesions in the gastroduodenal mucosa, which cause frequent pain and gastrointestinal hemorrhage, resulting in loss of the patient's quality of life [57].
Silva and Parente [58] studied the antiulcerogenic activity of a galactomannoglucan extracted from the pulp of $S$. oleracea. In this in vivo experiment, male Swiss mice exposed to absolute ethanol, a substance that attacks the mucous membrane of the stomach, presented widespread and intense gastric hyperemia, in addition to thick lesions (control group). On the other hand, the group treated with galactomannoglucan extracted from S. oleracea before the exposition to absolute ethanol, had a stomach close to normal, with a great reduction in gastric hyperemia and formation of lesions after the administration of ethanol, thus evidencing the antiulcerogenic and gastroprotective activity of this natural compound (Figure 2). This gastroprotective activity was attributed to the chemical structure of galactomannoglucan, which is characterized by an initial chain of $B-D$-galactose linked to (1-3) and terminal residues composed of $\alpha$-Dglucose linked to (1-4) and is similar to antiulcerogenic polysaccharides that can induce mucus production.

2.7. Anticholinesterase Activity. Alzheimer's is a neurodegenerative disease that progressively deteriorates mental functions. In this disease, the cholinergic function is affected, like acetylcholine, a neurotransmitter responsible for conducting electrical impulses from one nerve cell to another, is reduced in quantity due to the rapid hydrolysis carried out by acetylcholinesterase. Therefore, cholinesterase inhibitors can be used in the treatment of this disease because they would inhibit the premature hydrolysis caused by acetylcholinesterase $[59,60]$.

El-Hawary et al. [61] evaluated the anticholinesterase activity of hydroalcoholic extracts of leaves and fruits of S. romanzoffiana in an in vivo experiment (Figure 3 ). The experiment was based on the administration of doses of 50 and $100 \mathrm{mg} / \mathrm{kg}$.b.wt. of S. romanzoffiana extracts in rats for 2 

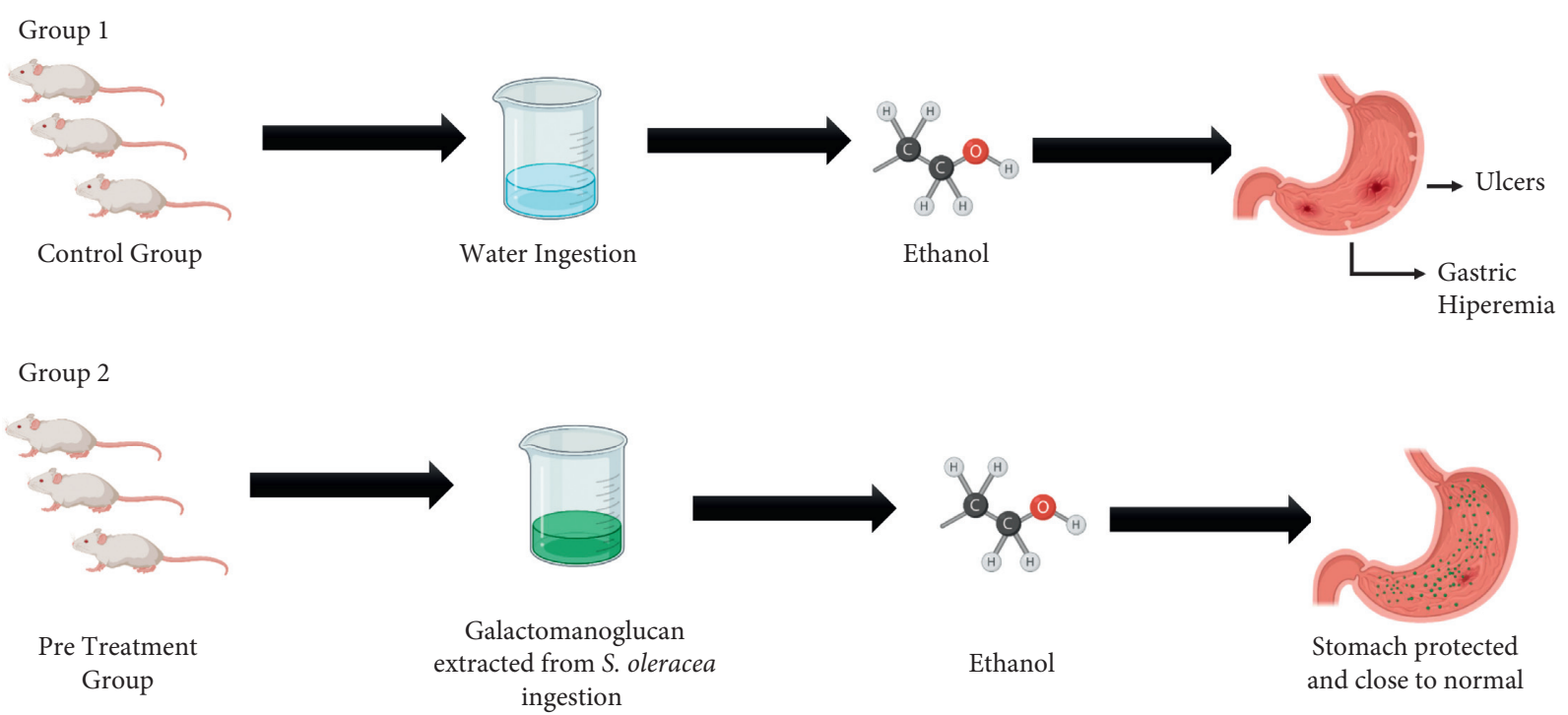

Figure 2: Gastroprotective action of galactomannoglucan extracted from S. oleracea (created with BioRender.com). Color indicates that Group 2 is treated with galactomannoglucan extracted from the pulp of S. oleracea and gets protected from ethanol action, but the control group treated only with water develops lesions and intense gastric hyperemia.

months. Treatment with $50 \mathrm{mg} / \mathrm{kg} . \mathrm{b} . w \mathrm{w}$. of the fruit extract resulted in a $21.5 \%$ reduction in acetylcholinesterase activity, whereas treatment with $100 \mathrm{mg} / \mathrm{kg}$.b.wt. of this same extract resulted in a reduction of $26.5 \%$. Treatment with $50 \mathrm{mg}$ / kg.b.wt. of the extract of the leaves of the jerivá, resulted in a reduction of $22 \%$ in the activity of acetylcholinesterase, already the treatment with $100 \mathrm{mg} / \mathrm{kg}$.b.wt. of this same extract resulted in a reduction of $29 \%$. Both extracts showed significant reductions in cholinesterase activity, mainly due to the richness of fatty acids, flavonoids, and stilbenoids present in the extracts.

2.8. Hypoglycemic Activity. Diabetes mellitus is a metabolic disease characterized by an increase in blood glucose. It is a disorder that affects more than 400 million people worldwide and presents many health risks, which can cause microvascular and macrovascular complications, kidney failure, myocardial infarction, stroke, and the need to amputate limbs, thus reducing the quality and life expectancy of individuals. One of the alternatives for treating diabetes mellitus is to delay glucose absorption by inhibiting carbohydrate hydrolysis enzymes, such as $\alpha$-glucosidase, and this inhibitory potential has been discovered in natural products $[62,63]$.

Lam et al. [26] evaluated the potential of S. romanzoffiana seed extract to inhibit $\alpha$-glucosidase. As a result, it was observed that $10 \mu \mathrm{g} / \mathrm{mL}$ of the ethanolic extract of $S$. romanzoffiana inhibited $\alpha$-glucosidase by $55 \%$ and the butanoic fraction of this extract at the same concentration was able to inhibit even more (73\%) (Figure 4). In addition, 8 compounds were identified in the extract and subsequently had their inhibitory activities evaluated, where 2 of them had excellent anti- $\alpha$-glucosidase potential. The first isolated compound was the stilbene-phenylpropanoid 13-hydroxycompasinol A. This compound showed an inhibitory effect with an $\mathrm{IC}_{50}$ of $6.5 \mu \mathrm{M}$, and the second compound was the dimeric stilbenoid scirpusin $\mathrm{C}$, which showed an even greater inhibitory effect, with an IC 50 of $4.9 \mu \mathrm{M}$.

In the study of Lam and Lee [64], 6 other compounds extracted from $S$. romanzoffiana had their hypoglycemic activity evaluated, and 4 of them showed anti- $\alpha$-glucosidase activity. Syagrusins A and B had ICs5o of 16.9 and $23.7 \mu \mathrm{M}$, respectively, 5-hydroxyapanol had $\mathrm{IC}_{50}$ of $12.8 \mu \mathrm{M}$, and the first phenylpropanoid had IC50 of $10.7 \mu \mathrm{M}$, thus, once again showing the potential that $S$. romanzoffiana extract and compounds have for the development of hypoglycemic drugs, especially stilbenoids.

2.9. Pharmacological Properties Suggested by Ethnobiological and Ethnopharmacological Studies. Ethnobiological and ethnopharmacological studies are greatly important for the discovery of new drugs of plant origin. These studies are based on research on the experiences of a community with the use of medicinal plants and their applications. From this, the most promising plants and genera are delimited, making the use of these plants more reliable and safer $[65,66]$.

Some researchers have already indicated the popular use of products of the Syagrus genus. In the study performed by Ribeiro et al. [67] in the northern microregion of Araguaia, in the state of Mato Grosso, the fruit of the Syagrus comosa (Mart.) plant, popularly known as bacuri, is used for conjunctivitis and $S$. oleracea for indigestion, diarrhea, and as an appetite stimulant. In the study performed by Rufino et al. 


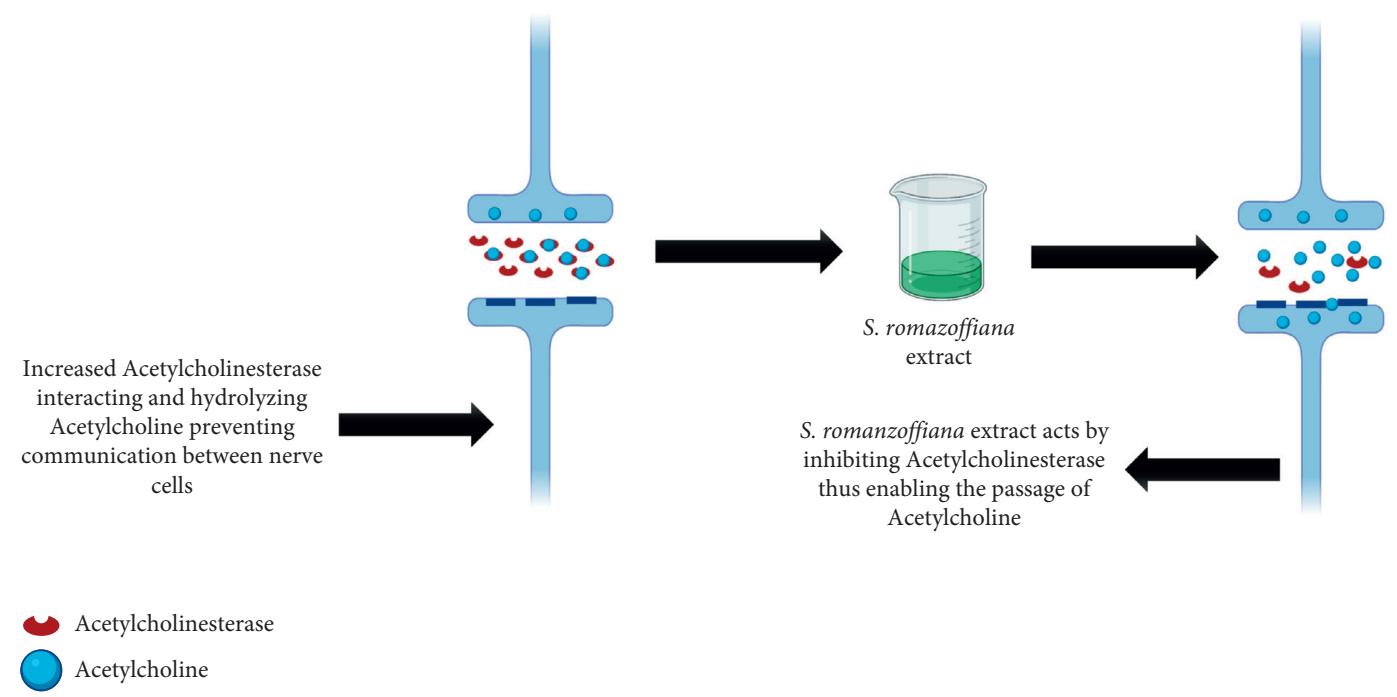

FIGURE 3: S. romanzoffiana extract slows acetylcholine hydrolysis (created with BioRender.com). Color indicates that S. romanzoffiana extract slows acetylcholine hydrolysis by inhibiting acetylcholinesterase action, consequently increasing the amount of acetylcholine and enabling the passage of acetylcholine.

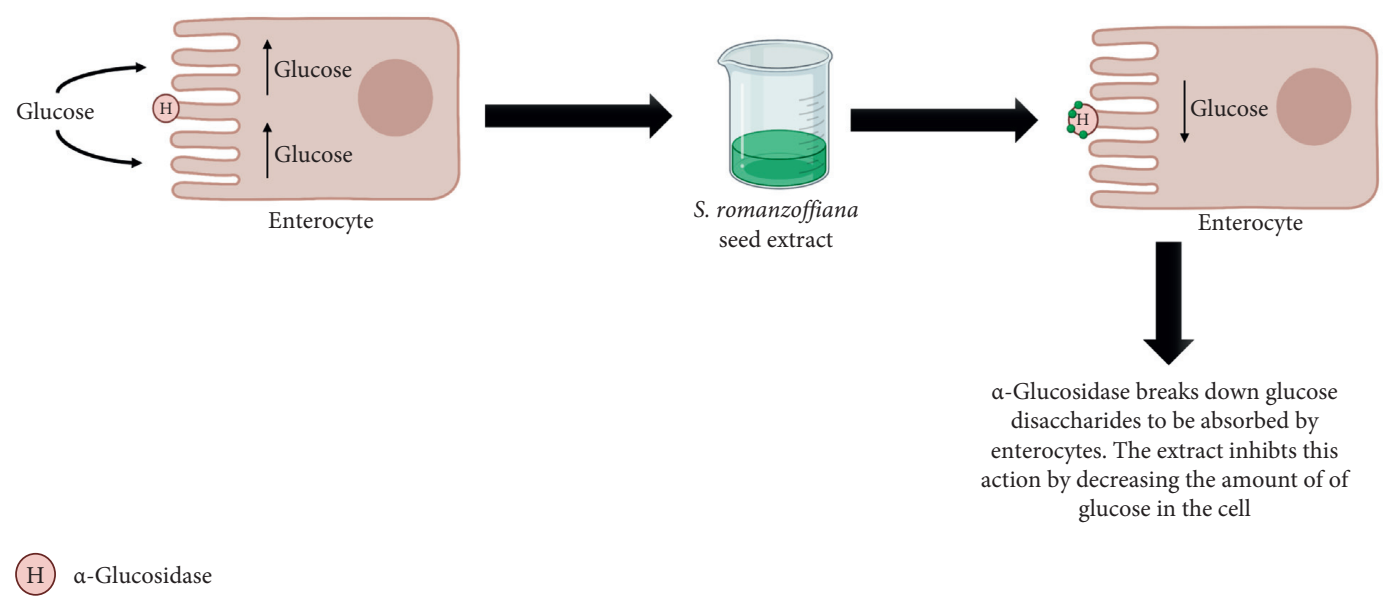

FIgURE 4: Decreased glucose absorption by the $\alpha$-glucosidase inhibition process caused by the extract of $S$. romanzoffiana, created with BioRender.com. Color indicates that the extract of $S$. romanzoffiana inhibits carbohydrate hydrolysis by the inhibition of $\alpha$-glucosidase, thus decreasing glucose absorption.

[68] in a community near the Catimbau Valley National Park, municipality of Buíque, Pernambuco, was reported that $S$. coronata is used for the treatment of eye inflammation, mycoses, wound healing, and pain in the spine.

Junior, Ladio, and Albuquerque [69], in the community of Carão, municipality of Altinho, in the harsh region of Pernambuco, indicated that the plant Syagrus cearensis, popularly known as coco-catolé, had anti-inflammatory activity. Individuals in that community reported improvement after using $S$. cearensis for pain caused by cuts, swelling of wounds, redness, and itchy eyes. However, despite the use of these plants in these communities, experimental studies must be conducted to prove their effectiveness and better elucidate the mechanisms of action of these natural products.

2.10. Other Applications. In addition to the pharmacological properties already mentioned in this article, plants of the Syagrus genus still have other possible applications (Table 2) $[13,14,70-80]$, mainly due to their chemical composition. The areas that stand out the most are biotechnology, for biodiesel production at an equal quality or better than the biodiesels on the market. Another success is in bioremediation, bringing fast, cheap, and efficient absorption of effluent materials. 
TABLe 2: Possible applications of plants of the Syagrus genus.

\begin{tabular}{|c|c|c|c|c|c|}
\hline Application area & Possible application & Product & Plant & $\begin{array}{l}\text { Popular } \\
\text { name }\end{array}$ & References \\
\hline Nanotechnology & $\begin{array}{l}\text { Transport of amphotericin B for topical } \\
\text { application }\end{array}$ & Microemulsion with oil & Syagrus cearensis & Coco-catolé & {$[65]$} \\
\hline Insecticides & $\begin{array}{l}\text { Promotion of the death of Aedes aegypti } \\
\text { larvae, as well as reduction in oviposition }\end{array}$ & Volatile oil & Syagrus coronata & $\begin{array}{l}\text { Ouricuri or } \\
\text { licuri }\end{array}$ & [66] \\
\hline \multirow{6}{*}{ Biotechnology } & Biodiesel production & Crude walnut oil & Syagrus coronata & $\begin{array}{l}\text { Ouricuri or } \\
\text { licuri }\end{array}$ & {$[67]$} \\
\hline & Biodiesel and bio oil production & Walnut & Syagrus coronata & $\begin{array}{l}\text { Ouricuri or } \\
\text { licuri }\end{array}$ & {$[12]$} \\
\hline & $\begin{array}{l}\text { Substrate for mycelium bioconversion } \\
\text { basidiomas and for ligninolytic enzyme } \\
\text { production by Ganoderma lucidum }\end{array}$ & $\begin{array}{l}\text { Agricultural waste (fruit } \\
\text { peels, leaves, and bracts) }\end{array}$ & Syagrus coronata & $\begin{array}{l}\text { Ouricuri or } \\
\text { licuri }\end{array}$ & {$[13]$} \\
\hline & Energy production & Nutshell & Syagrus coronata & $\begin{array}{l}\text { Ouricuri or } \\
\text { licuri }\end{array}$ & {$[68]$} \\
\hline & Biodiesel production & Oil from seeds & $\begin{array}{l}\text { Syagrus } \\
\text { romanzoffiana }\end{array}$ & Jerivá & {$[69]$} \\
\hline & Biodiesel production & Almonds & Syagrus cearensis & Coco-catolé & [70] \\
\hline \multirow{5}{*}{ Bioremediation } & $\begin{array}{c}\text { Bioremoval of methylene blue from aqueous } \\
\text { solutions }\end{array}$ & Fibers & Syagrus coronata & $\begin{array}{l}\text { Ouricuri or } \\
\text { licuri }\end{array}$ & {$[71]$} \\
\hline & $\begin{array}{c}\text { Bioremoval of methylene blue from aqueous } \\
\text { solutions }\end{array}$ & $\begin{array}{l}\text { Activated carbon obtained } \\
\text { from the endocarp }\end{array}$ & Syagrus oleracea & Guariroba & {$[72]$} \\
\hline & Bioremoval of $\mathrm{Cu}$ (II) from aqueous solutions & $\begin{array}{l}\text { Coal obtained from the } \\
\text { fruit peel }\end{array}$ & Syagrus coronata & $\begin{array}{l}\text { Ouricuri or } \\
\text { licuri }\end{array}$ & {$[73]$} \\
\hline & $\begin{array}{c}\text { Biosorption of ciprofloxacin from aquatic } \\
\text { effluents }\end{array}$ & $\begin{array}{l}\text { Activated carbon obtained } \\
\text { from the endocarp }\end{array}$ & $\begin{array}{l}\text { Syagrus } \\
\text { romanzoffiana }\end{array}$ & Jerivá & {$[74]$} \\
\hline & Biosorption of diclofenac in aquatic effluents & $\begin{array}{l}\text { Material using charcoal } \\
\text { from the endocarp }\end{array}$ & Syagrus coronata & $\begin{array}{l}\text { Ouricuri or } \\
\text { licuri }\end{array}$ & {$[75]$} \\
\hline
\end{tabular}

\section{Conclusion}

Syagrus genus has a large group of palm trees rich in bioactive compounds, presenting several pharmacological properties that can be used from facing bacterial and parasitic infections to the treatment and/or prevention of chronic diseases such as diabetes and Alzheimer's disease. In addition, they show versatility to be used in other areas, such as the production of biodiesel, energy, enzymes, and among others. Syagrus coronata stands out when it comes to bacterial and parasitic infections, and Syagrus romanzoffiana stands out mostly against chronic diseases, showing anticholinesterase and anti $\alpha$-glucosidase activity. In addition, they show versatility to be used in other areas, such as the production of biodiesel, energy, enzymes, and among others. However, despite demonstrating potential, further studies should be conducted to better elucidate the mechanism of action, pharmacokinetics, and possible side effects of these natural products.

\section{Data Availability}

This review article was carried out by searching for review and original articles related to the proposed theme available on online databases, such as U.S. National Library of Medicine (PubMed), ScienceDirect, Scopus, and Scientific Electronic Library Online (SciELO), published in either Portuguese or English between 2005 and 2021.

\section{Conflicts of Interest}

The authors declare that they have no conflicts of interest.

\section{Acknowledgments}

Davi de Lacerda Coriolano thanks the Institutional Program of Scientific Initiation Scholarships (PIBIC/UFPE/CNPq).

\section{References}

[1] J. L. A. Campos and U. P. Albuquerque, "Indicators of conservation priorities for medicinal plants from seasonal dry forests of northeastern Brazil," Ecological Indicators, vol. 121, Article ID 106993, 2021.

[2] T. Sen and S. K. Samanta, "Medicinal plants, human health and biodiversity: a broad review," in Biotechnological Applications of Biodiversity Advances in Biochemical Engineering/ Biotechnology, J. Mukherjee, Ed., Springer, Berlin, Germany, pp. 59-110, 2014.

[3] B. Yang, Y. Xie, M. Guo, M. H. Rosner, H. Yang, and C. Ronco, "Nephrotoxicity and Chinese herbal medicine," Clinical Journal of the American Society of Nephrology, vol. 13, no. 10, pp. 1605-1611, 2018.

[4] A. Dafni and B. Böck, "Medicinal plants of the bible-revisited," Journal of Ethnobiology and Ethnomedicine, vol. 15, no. 1, p. 57, 2019.

[5] M. Gunjan, T. W. Naing, R. S. Saini, A. Ahmad, J. R. Naidu, and I. Kumar, "Marketing trends \& future prospects of herbal medicine in the treatment of various disease," World Journal of Pharmaceutical Research, vol. 4, no. 9, pp. 132-155, 2015. 
[6] World Health Organization, WHO Global Report on Traditional and Complementary Medicine 2019, World Health Organization, Geneva, Switzerland, 2019.

[7] D. A. Dias, S. Urban, and U. Roessner, "A historical overview of natural products in drug discovery," Metabolites, vol. 2, no. 2, pp. 303-336, 2012.

[8] B. David, J.-L. Wolfender, and D. A. Dias, "The pharmaceutical industry and natural products: historical status and new trends," Phytochemistry Reviews, vol. 14, no. 2, pp. 299-315, 2015.

[9] J. N. Kabera, E. Semana, A. R. Mussa, and X. He, "Plant secondary metabolites: biosynthesis, classification, function and pharmacological properties," Journal of Pharmacy and Pharmacology, vol. 2, pp. 377-392, 2014.

[10] S. Pagare, M. Bhatia, N. Tripathi, S. Pagare, and Y. K. Bansal, "Secondary metabolites of plants and their role: overview," Current Trends in Biotechnology and Pharmacy, vol. 9, no. 3, pp. 293-304, 2015.

[11] T. A. Meraj, J. Fu, M. A. Raza et al., "Transcriptional factors regulate plant stress responses through mediating secondary metabolism," Genes, vol. 11, no. 4, p. 346, 2020.

[12] A. Karmakar, S. Karmakar, and S. Mukherjee, "Properties of various plants and animals feedstocks for biodiesel production," Bioresource Technology, vol. 101, no. 19, pp. 7201-7210, 2010.

[13] O. K. Iha, F. C. S. C. Alves, P. A. Z. Suarez et al., "Physicochemical properties of Syagrus coronata and Acrocomia aculeata oils for biofuel production," Industrial Crops and Products, vol. 62, pp. 318-322, 2014.

[14] T. A. de Menezes, A. S. d. R. Bispo, M. G. B. Koblitz, L. P. D. S. Vandenberghe, H. M. Kamida, and A. Goes-Neto, "Production of basidiomata and ligninolytic enzymes by the lingzhi or reishi medicinal mushroom, Ganoderma lucidum (agaricomycetes), in licuri (Syagrus coronata) wastes in Brazil," International Journal of Medicinal Mushrooms, vol. 18, no. 12, pp. 1141-1149, 2016.

[15] L. R. Schneider, D. C. Dos Santos, A. D. Campos, and R. G. Lund, "The phytochemistry and pharmacology of Butia sp.: a systematic review and an overview of the technological monitoring process," Phytotherapy Research, vol. 31, no. 10, pp. 1495-1503, 2017.

[16] T. S. S. de Almeida Magalhães, P. C. de Oliveira Macedo, A. Converti, and Á. A. Neves de Lima, "The use of Euterpe oleracea Mart. As a new perspective for disease treatment and prevention," Biomolecules, vol. 10, no. 6, p. 813, 2020.

[17] A. Cardoso, S. de Liz, D. Rieger et al., "An update on the biological activities of Euterpe edulis (juçara)," Planta Medica, vol. 84, no. 8, pp. 487-499, 2018.

[18] M. T. Reddy, M. Kalpana, N. Sivaraj, V. Kamala, S. R. Pandravada, and N. Sunil, "Indigenous traditional knowledge on health and equitable benefits of oil palm (Elaeis spp.)," OALib, vol. 6, no. 1, pp. 1-25, 2019.

[19] L. R. Noblick, "A revision of the genus Syagrus (Arecaceae)," Phytotaxa, vol. 294, no. 1, pp. 1-262, 2017.

[20] N. S. Vitoria, N. G. Soares Fortes, M. A. Lima dos Santos, and R. L. Barbosa, "Mycota (Ascomycota) of Syagrus coronata (Mart.) Becc., Raso da Catarina Ecological Station, Brazil: new records," Acta Brasiliensis, vol. 4, no. 2, pp. 110-120, 2020.

[21] N. Jorge, A. C. da Silva, and C. M. Veronezi, "Syagrus romanzoffiana," in Fruits of the Brazilian Cerrado: Composition and Functional Benefits, F. F. de Lima, C. H. Lescano, and I. P. de Oliveira, Eds., Springer Nature, New York, NY, USA, pp. 141-159, 2021.
[22] M. C. Coimbra and N. Jorge, "Fatty acids and bioactive compounds of the pulps and kernels of Brazilian palm species, guariroba (Syagrus oleraces ), jerivá (Syagrus romanzoffiana) and macaúba (Acrocomia aculeata )," Journal of the Science of Food and Agriculture, vol. 92, no. 3, pp. 679-684, 2011.

[23] A. F. D. S. Hughes, F. G. D. Lima, A. M. Lucchese, A. Góes Neto, and A. P. T. Uetanabaro, "Antimicrobial activity of Syagrus coronata (Martius) beccari," Brazilian Archives of Biology and Technology, vol. 56, no. 2, pp. 269-274, 2013.

[24] I. A. Rodrigues, D. S. Alviano, M. T. Gomes et al., "In vitro anti-Leishmania amazonensis activity of the polymeric procyanidin-rich aqueous extract from Syagrus coronata," Journal of Medicinal Plants Research, vol. 5, no. 16, pp. 3781-3790, 2011.

[25] S. Belviso, D. Ghirardello, M. Giordano et al., "Phenolic composition, antioxidant capacity and volatile compounds of licuri (Syagrus coronata (Martius) Beccari) fruits as affected by the traditional roasting process," Food Research International, vol. 51, no. 1, pp. 39-45, 2013.

[26] S.-H. Lam, J.-M. Chen, C.-J. Kang, C.-H. Chen, and S.-S. Lee, " $\alpha$-glucosidase inhibitors from the seeds of Syagrus romanzoffiana," Phytochemistry, vol. 69, no. 5, pp. 1173-1178, 2008.

[27] C. M. A. S. Bessa, R. S. do Nascimento, R. C. C. Alves et al., "Syagrus coronata seed oils have antimicrobial action against multidrug-resistant Staphylococcus aureus," Journal of Medicinal Plants Research, vol. 10, no. 23, pp. 310-317, 2016.

[28] U. Anand, N. Jacobo-Herrera, A. Altemimi, and N. Lakhssassi, "A comprehensive review on medicinal plants as antimicrobial therapeutics: potential avenues of biocompatible drug discovery," Metabolites, vol. 9, no. 11, p. 258, 2019.

[29] E. Christaki, M. Marcou, and A. Tofarides, “Antimicrobial resistance in bacteria: mechanisms, evolution, and persistence," Journal of Molecular Evolution, vol. 88, no. 1, pp. 26-40, 2020.

[30] C. S. Silveira, C. M. Pessanha, M. C. S. Lourenço, I. Neves Júnior, F. S. Menezes, and M. A. C. Kaplan, "Atividade antimicrobiana dos frutos de Syagrus oleracea e Mauritia vinifera," Revista Brasileira de Farmacognosia, vol. 15, no. 2, pp. 143-148, 2005.

[31] B. Souza dos Santos, C. M. Bezerra Filho, J. A. Alves do Nascimento Junior et al., "Anti-staphylococcal activity of Syagrus coronata essential oil: biofilm eradication and in vivo action on Galleria mellonela infection model," Microbial Pathogenesis, vol. 131, pp. 150-157, 2019.

[32] F. M. Dayrit, "The properties of lauric acid and their significance in coconut oil," Journal of the American Oil Chemists' Society, vol. 92, no. 1, pp. 1-15, 2015.

[33] S. A. Kim and M. S. Rhee, "Highly enhanced bactericidal effects of medium chain fatty acids (caprylic, capric, and lauric acid) combined with edible plant essential oils (carvacrol, eugenol, $\beta$-resorcylic acid, trans -cinnamaldehyde, thymol, and vanillin) against Escherichia coli O157:H7," Food Control, vol. 60 , pp. $447-454,2016$.

[34] H. W. Kim, Y. S. Seok, and M. S. Rhee, "Synergistic staphylocidal interaction of benzoic acid derivatives (benzoic acid, 4-hydroxybenzoic acid and $\beta$-resorcylic acid) and capric acid: mechanism and verification study using artificial skin," Journal of Antimicrobial Chemotherapy, vol. 75, no. 3, pp. 571-575, 2020.

[35] T. G. dos Santos Souza, M. M. da Silva, G. S. Feitoza et al., "Biological safety of Syagrus coronata (Mart.) Becc. fixed oil: cytotoxicity, acute oral toxicity, and genotoxicity studies," 
Journal of Ethnopharmacology, vol. 272, Article ID 113941, 2021.

[36] H. Boudarel, J. D. Mathias, B. Blaysat, and M. Grédiac, "Towards standardized mechanical characterization of microbial biofilms: analysis and critical review," NPJ Biofilms and Microbiomes, vol. 4, no. 1, pp. 15-17, 2018.

[37] D. de Lacerda Coriolano, J. B. de Souza, E. V. Bueno, S. M. D. F. R. Medeiros, I. D. L. Cavalcanti, and I. M. F. Cavalcanti, "Antibacterial and antibiofilm potential of silver nanoparticles against antibiotic-sensitive and multidrug-resistant Pseudomonas aeruginosa strains," Brazilian Journal of Microbiology, vol. 52, no. 1, pp. 267-278, 2020.

[38] J. N. Junior, N. G. P. Maciel, B. S. Santos et al., "Evaluation of the antibiofilm activity of the essential oil of Syagrus coronata against Proteus mirabilis isolates," in Exploring Microorganisms: Recent Advances in Applied Microbiology, A. MéndezVilas, Ed., pp. 252-255, Brown Walker Press, Irvine, CA, USA, 2018.

[39] P. Kumar, J.-H. Lee, H. Beyenal, and J. Lee, "Fatty acids as antibiofilm and antivirulence agents," Trends in Microbiology, vol. 28 , no. 9, pp. 753-768, 2020.

[40] A. Alison Kealey and R. Robert Smith, "Neglected tropical diseases: infection, modeling, and control," Journal of Health Care for the Poor and Underserved, vol. 21, no. 1, pp. 53-69, 2010.

[41] C. M. Beaumier, P. M. Gillespie, P. J. Hotez, and M. E. Bottazzi, "New vaccines for neglected parasitic diseases and dengue," Translational Research, vol. 162, no. 3, pp. 144-155, 2013.

[42] World Health Organization (WHO), Global Leishmaniasis Surveillance, 2017-2018, And First Report On 5 Additional Indicators, WHO, vol. 95, no. 25, , pp. 265-280, Geneva, Switzerland, 2020.

[43] J. B. Souza, D. L. Coriolano, S. O. Alves et al., "Nanocarreadores como alternativa para veiculação da anfotericina B no tratamento da leishmaniose visceral humana," in Pesquisas em temas de ciências da saúde, E. S. R. Souza, Ed., pp. 87-101, Rfb Editora, Belém, Brazil, 2020.

[44] J. A. Pérez-Molina and I. Molina, "Chagas disease," The Lancet, vol. 391, no. 10115, pp. 82-94, 2018.

[45] World Health Organization (WHO), "Chagas disease (also known as american trypanosomiasis)," 2020, https://www. who.int/news-room/fact-sheets/detail/chagas-disease(american-trypanosomiasis.

[46] L. I. Oliveira de Souza, P. C. Bezzera-Silva, D. M. do Amaral Ferraz Navarro et al., "The chemical composition and trypanocidal activity of volatile oils from Brazilian Caatinga plants," Biomedicine \& Pharmacotherapy, vol. 96, pp. 10551064, 2017.

[47] R. A. S. Campos, F. Vianello, L. F. Fleuri, V. A. Pedrosa, P. Vanzani, and G. P. P. Lima, "Antioxidants in Brazilian plant species," in Food Quality, Safety and Technology, G. Lima and F. Vianello, Eds., Springer, Vienna, Austria, 2013.

[48] A. M. Pisoschi, A. Pop, C. Cimpeanu, and G. Predoi, “Antioxidant capacity determination in plants and plant-derived products: a review," Oxidative Medicine and Cellular Longevity, vol. 2016, Article ID 9130976, 36 pages, 2016.

[49] A. C. Andrade, J. F. U. Marinho, A. C. de Souza et al., "Prebiotic potential of pulp and kernel cake from Jerivá (Syagrus romanzoffiana) and Macaúba palm fruits (Acrocomia aculeata)," Food Research International, vol. 136, Article ID 109595, 2020.

[50] M. C. Coimbra and N. Jorge, "Proximate composition of guariroba (Syagrus oleracea), jerivá (Syagrus romanzoffiana) and macaúba (Acrocomia aculeata) palm fruits," Food Research International, vol. 44, no. 7, pp. 2139-2142, 2011.

[51] K. Gul, A. Tak, A. K. Singh, P. Singh, B. Yousuf, and A. A. Wani, "Chemistry, encapsulation, and health benefits of $\beta$-carotene-a review," Cogent Food \& Agriculture, vol. 1, no. 1, Article ID 1018696, 2015.

[52] M. S. Brewer, "Natural antioxidants: sources, compounds, mechanisms of action, and potential applications," Comprehensive Reviews in Food Science and Food Safety, vol. 10, no. 4, pp. 221-247, 2011.

[53] C. Silva, R. Herdeiro, C. Mathias et al., "Evaluation of antioxidant activity of Brazilian plants," Pharmacological Research, vol. 52, no. 3, pp. 229-233, 2005.

[54] E. M. Siqueira, F. R. Rosa, A. M. Fustinoni, L. P. de Sant'Ana, and S. F. Arruda, "Brazilian savanna fruits contain higher bioactive compounds content and higher antioxidant activity relative to the conventional red delicious apple," PLoS One, vol. 8, no. 8, Article ID e72826, 2013.

[55] R. M. Lamuel-Raventos and M.-P. S. Onge, "Prebiotic nut compounds and human microbiota," Critical Reviews in Food Science and Nutrition, vol. 57, no. 14, pp. 3154-3163, 2017.

[56] M. Roberfroid, G. R. Gibson, L. Hoyles et al., "Prebiotic effects: metabolic and health benefits," British Journal of $\mathrm{Nu}$ trition, vol. 104, no. S2, pp. S1-S63, 2010.

[57] J. J. Dunlap and S. Patterson, "Peptic ulcer disease," Gastroenterology Nursing, vol. 42, no. 5, pp. 451-454, 2019.

[58] B. P. da Silva and J. P. Parente, "Chemical properties and antiulcerogenic activity of a galactomannoglucan from Syagrus oleracea," Food Chemistry, vol. 123, no. 4, pp. 1076-1080, 2010.

[59] P. Anand and B. Singh, "A review on cholinesterase inhibitors for Alzheimer's disease," Archives of Pharmacal Research, vol. 36, no. 4, pp. 375-399, 2013.

[60] A. Chatonnet, N. Lenfant, P. Marchot, and M. E. Selkirk, "Natural genomic amplification of cholinesterase genes in animals," Journal of Neurochemistry, vol. 142, pp. 73-81, 2017.

[61] S. S. El-Hawary, F. I. Fathy, A. A. Sleem, F. A. Morsy, M. S. Khadar, and M. K. Mansour, "Anticholinesterase activity and metabolite profiling of Syagrus romanzoffiana (Cham.) Glassman leaves and fruits via UPLC-QTOF-PDA-MS," Natural Product Research, vol. 35, no. 10, pp. 1671-1675, 2019.

[62] J. E. Kanter and K. E. Bornfeldt, "Impact of diabetes mellitus," Arteriosclerosis, Thrombosis, and Vascular Biology, vol. 36, no. 6, pp. 1049-1053, 2016.

[63] H. Teng and L. Chen, " $\alpha$-glucosidase and $\alpha$-amylase inhibitors from seed oil: a review of liposoluble substance to treat diabetes," Critical Reviews in Food Science and Nutrition, vol. 57, no. 16, pp. 3438-3448, 2017.

[64] S.-H. Lam and S.-S. Lee, "Unusual stilbenoids and a stilbenolignan from seeds of Syagrus romanzoffiana," Phytochemistry, vol. 71, no. 7, pp. 792-797, 2010.

[65] V. de Carvalho Nilo Bitu, V. de Carvalho Nilo Bitu, E. F. F. Matias et al., "Ethnopharmacological study of plants sold for therapeutic purposes in public markets in Northeast Brazil," Journal of Ethnopharmacology, vol. 172, pp. 265-272, 2015.

[66] R. S. F. R. Sarquis, Í. Rodrigues Sarquis, I. Rodrigues Sarquis et al., "The use of medicinal plants in the riverside community of the Mazagão river in the Brazilian Amazon, Amapá, Brazil: ethnobotanical and ethnopharmacological studies," EvidenceBased Complementary and Alternative Medicine, vol. 2019, Article ID 6087509, 25 pages, 2019. 
[67] R. V. Ribeiro, I. G. C. Bieski, S. O. Balogun, and D. T. D. O. Martins, "Ethnobotanical study of medicinal plants used by ribeirinhos in the north Araguaia microregion, Mato Grosso, Brazil," Journal of Ethnopharmacology, vol. 205, pp. 69-102, 2017.

[68] M. U. D. L. Rufino, J. T. D. M. Costa, V. A. D. Silva, and L. D. H. C. Andrade, "Conhecimento e uso do ouricuri (Syagrus coronata) e do babaçu (Orbignya phalerata) em Buíque, PE, Brasil," Acta Botanica Brasilica, vol. 22, no. 4, pp. 1141-1149, 2008.

[69] W. S. F. Júnior, A. H. Ladio, and U. P. d. Albuquerque, "Resilience and adaptation in the use of medicinal plants with suspected anti-inflammatory activity in the Brazilian Northeast," Journal of Ethnopharmacology, vol. 138, no. 1, pp. 238-252, 2011.

[70] G. D. Sousa, J. Kishishita, K. A. S. Aquino, O. A. F. Presgrave, L. B. Leal, and D. P. Santana, "Biopharmaceutical assessment and irritation potential of microemulsions and conventional systems containing oil from Syagrus cearensis for topical delivery of amphotericin B using alternative methods," AAPS PharmSciTech, vol. 18, no. 5, pp. 1833-1842, 2017.

[71] L. M. M. Santos, J. S. Nascimento, M. A. G. Santos et al., "Fatty acid-rich volatile oil from Syagrus coronata seeds has larvicidal and oviposition-deterrent activities against Aedes aegypti," Physiological and Molecular Plant Pathology, vol. 100, pp. 35-40, 2017.

[72] K. Teixeira da Silva de La Salles, S. M. P. Meneghetti, W. Ferreira de La Salles et al., "Characterization of Syagrus coronata (Mart.) Becc. oil and properties of methyl esters for use as biodiesel," Industrial Crops and Products, vol. 32, no. 3, pp. 518-521, 2010.

[73] V. Scalet, A. L. da Róz, L. R. O. Santos et al., "Waste of the Licuri (syagrus coronata) nut shells: an alternative energy source," Revista Brasileira de Energias Renováveis, vol. 8, no. 3 , 2019.

[74] M. A. C. Moreira, M. E. Payret Arrúa, A. C. Antunes et al., "Characterization of Syagrus romanzoffiana oil aiming at biodiesel production," Industrial Crops and Products, vol. 48, pp. 57-60, 2013.

[75] C. V. P. Pascoal, A. L. L. Oliveira, D. D. Figueiredo, and J. C. C. Assunção, "Optimization and kinetic study of ultrasonic-mediated in situ transesterification for biodiesel production from the almonds of Syagrus cearensis," Renewable Energy, vol. 147, pp. 1815-1824, 2020.

[76] L. Meili, T. S. da Silva, D. C. Henrique et al., "Ouricuri (Syagrus coronata) fiber: a novel biosorbent to remove methylene blue from aqueous solutions," Water Science and Technology, vol. 75, no. 1, pp. 106-114, 2017.

[77] K. J. L. dos Santos, G. E. de Souza dos Santos, Í. M. G. L. de Sá et al., "Syagrus oleracea-activated carbon prepared by vacuum pyrolysis for methylene blue adsorption," Environmental Science and Pollution Research, vol. 26, no. 16, pp. 1647016481, 2019.

[78] Í. P. Sá, O. S. E. Filho, N. Guedes et al., "Study of the Cu (II) removal from aqueous medium using carbon prepared from licuri shell (syagrus coronata)," Revista Virtual de Química, vol. 9, no. 5, pp. 2121-2134, 2017.

[79] C. de Oliveira Carvalho, D. L. Costa Rodrigues, É. C. Lima, C. Santanna Umpierres, D. F. Caicedo Chaguezac, and F. Machado Machado, "Kinetic, equilibrium, and thermodynamic studies on the adsorption of ciprofloxacin by activated carbon produced from Jerivá (Syagrus romanzoffiana)," Environmental Science and Pollution Research, vol. 26, no. 5, pp. 4690-4702, 2019.
[80] G. E. de Souza dos Santos, A. H. Ide, J. L. S. Duarte, G. McKay, A. O. S. Silva, and L. Meili, "Adsorption of anti-inflammatory drug diclofenac by $\mathrm{MgAl} /$ layered double hydroxide supported on Syagrus coronata biochar," Powder Technology, vol. 364, pp. 229-240, 2020. 